\title{
BOTULISM AND BIOTERRORISM: HOW SERIOUS IS THIS PROBLEM?
}

\author{
Jiři Patočka ${ }^{1,4}$, Miroslav Špliňo ${ }^{2,5}$, Vladimír Měrka ${ }^{3}$
}

University of Defence, Faculty of Military Health Sciences, Hradec Králové, Czech Republic: Department of Toxicology ${ }^{1}$; Department of Epidemiology2; Centre of Information Technologies33; University of South Bohemia, České Budějovice, Faculty of Health and Social Studies, Czech Republic: Department of Radiology and Toxicology4; University Hospital Hradec Králové, Czech Republic: Department of Clinical Microbiology 5

\begin{abstract}
Summary: Botulism is a potentially lethal disease caused by one of seven homologous neurotoxic proteins usually produced by the bacterium, Clostridium botulinum. This neuromuscular disorder occurs through an exquisite series of molecular events, ultimately ending with the arrest of acetylcholine release and hence, flaccid paralysis. There are three types of botulism: food, wound, and infant botulism. Most strains of the bacterium produce a potent, respiratory muscle-paralyzing neurotoxin, botulinum toxin (BTX). It can lead to death unless appropriate therapy is promptly initiated. Due to the severity and potency of BTX, its importance as a biological weapon is of major concern to public health officials. Nevertheless, BTX is also medicament.
\end{abstract}

Key words: Botulism; Botulinum toxin; Clostridium botulinum; Bioterrorism

\section{Introduction}

The fears and predictions of attacks with biological weapons, which were increasing at the close of the twentieth century, were transformed into reality not long after September 11, 2001, when several anthrax-laden letters were sent through the U.S. postal system (25). The attack challenged our medical preparedness and scientific understanding of the epidemiology of biothreat agents. Bioterrorism is a reality not only in the United States but throughout the world (2). Intelligence sources indicate there are many countries and terrorist organizations that either possess biological weapons or are attempting to procure them. In the future it is likely that we will experience additional acts of bioterrorism (7). The biomedical community has begun to seek new ways of protecting against such future threats of bioterrorism $(15,44)$.

The biological agents that have been identified as posing the greatest threat are variola major (smallpox), Bacillus anthracis (anthrax), Yersinia pestis (plague), Francisella tularensis (tularaemia), filoviruses (Ebola hemorrrhagic fever and Marburg hemorrhagic fever), arenaviruses Lassa (Lassa fever), Junin (Argentine hemorrhagic fever) and Clostridium botulinum toxin (botulism) (3).

Clostridium botulinum toxins are neurotoxins that act to prevent the release of acetylcholine presynaptically and thus block neurotransmission. An aerosolized or foodborne botulinum toxin weapon would cause acute flaccid paralysis with prominent bulbar palsies (23). The Working Group on Civilian Biodefense* has developed consensus-based recommendations for measures to be taken by medical and public health professionals if botulinum toxin (BTX) is used as a biological weapon against a civilian population (1).

\section{Botulism}

Botulism is a rare but serious muscle-paralyzing disease caused by a nerve toxin that is produced by the bacterium Clostridium botulinum. There are three main kinds of botulism. Foodborne botulism is caused by eating foods that contain the botulism toxin. Foodborne botulism occurs when a person ingests a pre-formed toxin that leads to illness within a few hours to days. Foodborne botulism is a public health emergency because the contaminated food may still be available to other persons besides the patient. Infant botulism is caused by consuming the spores of the botulinum bacteria, which then grow in the intestines and release toxin. This kind of botulism occurs in a small number of susceptible infants each year who harbor C. botulinum in their intestinal tract. Wound botulism is caused by toxin produced from a wound infected with $C$. botulinum. All forms of botulism can be fatal and are considered medical emergencies. Foodborne botulism can be especially dange-

\footnotetext{
* The working group included 23 representatives from academic, government, and private institutions with expertise in public health, emergency management, and clinical medicine.
} 
rous because many people can be poisoned by eating contaminated food. Foodborne botulism is the most common form of disease in adults (6).

C. botulinum is the name of a group of bacteria commonly found in soil. These rod-shaped organisms grow best in anaerobic conditions. The bacteria form spores which allow them to survive in a dormant state until exposed to conditions that can support their growth. Under the right conditions, these bacteria produce toxins.There are seven types of botulinum toxins (BTXs) designated by the letters A through $\mathrm{G}$; only types A, B, E and F cause illness in humans. An inhalational form of botulism is also possible. BTX exposure may occur in both forms as agents of bioterrorism (21).

\section{Botulinum toxin}

BTX is produced by Clostridium botulinum, which is a gram-positive anaerobic bacterium. BTX is broken into 7 neurotoxins (labeled as types A, B, C [C1, C2], D, E, F, and $\mathrm{G})$, which are antigenically and serologically distinct but structurally similar. The BTX molecule is synthesized as a single chain $(150 \mathrm{kDa})$ and then cleaved to form the dichain molecule with a disulfide bridge. The light chain $(\sim 50 \mathrm{kDa}-$ amino acids $1-448)$ acts as a zinc $\left(\mathrm{Zn}^{2+}\right)$ endopeptidase with proteolytic activity located at the N-terminal end (34). The heavy chain ( $\sim 100 \mathrm{kDa}-$ amino acids 449-1280) provides cholinergic specificity and thus binding the toxin to presynaptic receptors, and it promotes light chain translocation across the endosomal membrane (18). BTX is the single most poisonous substance known, with very small amounts causing paralysis and death. The highest toxicity is attached to BTX-A. The comparative toxicity of selected bacterial toxins and some organophosphate nerve agents is summarized in Table 1.

Tab. 1: Comparative Toxicity of Selected Toxins and Organophosphate Nerve Agents in Laboratory Mice (intraperitoneal administration).

\begin{tabular}{|l|c|}
\hline Toxic agent & Toxicity $\mathbf{L D}_{\mathbf{5 0}}\left(\boldsymbol{\mu \mathbf { g . k g }} \mathbf{k g}^{-\mathbf{1}}\right)$ \\
\hline Botulinum toxin A & 0.001 \\
\hline Shiga toxin & 0.002 \\
\hline Tetanus toxin & 0.002 \\
\hline Diphteria toxin & 0.10 \\
\hline VX & 15.0 \\
\hline Soman & 64.0 \\
\hline Sarin & 100.0 \\
\hline
\end{tabular}

According to Eitzen et al. 1998.

The toxicity of BTX is believed to be a result of three functional domains acting in a three-step mechanism: binding, entering, and catalyzing a specific reaction within the cell. The idea that BTX shares this three-step model of toxicity was first proposed by Simpson (39). The first step in- volves a binding interaction between the 50-kDa binding domain and a cell surface receptor on the pre-synaptic membrane. BTX is thought to be internalized into an endosome via receptor-mediated endocytosis. The acidic $\mathrm{pH}$ of the endosome is believed to then cause a conformational change in the 50-kDa translocation domain which allows it to interact with the endosomal membrane and form a channel. The $50-\mathrm{kDa}$ catalytic domain is translocated across the membrane, released from its disulfide linkage, and left free in the cytosol. The catalytic domain of each BTX serotype is a zinc-dependent endopeptidase which targets specific sequences of proteins involved in vesicle-docking and membrane fusion. BTX's cleavage of a peptide bond in SNAP-25 (synaptosomal associated protein of $25-\mathrm{kDa}$ ) results in inhibition of the acetylcholine release from the axon and, ultimately, paralysis (20).

\section{Stability}

Despite its extreme potency, botulinum toxin is easily destroyed. Heating to an internal temperature of $85^{\circ} \mathrm{C}$ for at least 5 minutes will detoxify contaminated food or drink (37). Persistence of aerosolized botulinum toxin at a site of deliberate release is determined by atmospheric conditions and the particle size of the aerosol. Extremes of temperature and humidity will degrade the toxin, while fine aerosols will eventually dissipate into the atmosphere. Depending on the weather, aerosolized toxin has been estimated to decay at between less than $1 \%$ to $4 \%$ per minute (8). At a decay rate of $1 \%$ per minute, substantial inactivation of toxin occurs within 2 days after aerosolization.

Recognition of a covert release of finely aerosolized botulinum toxin would probably occur too late to prevent additional exposures. When exposure is anticipated, some protection may be conferred by covering the mouth and nose with clothing such as an undershirt, shirt, scarf, or handkerchief (46). In contrast with mucosal surfaces, intact skin is impermeable to botulinum toxin.

Spores of $C$. botulinum are ubiquitous in the environment (19), but growth and elaboration of toxin occur only under particular conditions that include an anaerobic, lowsalt, low-acid environment. Bacterial growth is inhibited by refrigeration below $4^{\circ} \mathrm{C}$, heating above $121^{\circ} \mathrm{C}$, high water activity, or acidity $(\mathrm{pH}<4.5)$. Spores are inactivated by heating to $121^{\circ} \mathrm{C}$ under pressure for at least 20 minutes.

\section{Identification}

The best diagnostic sample for immunologic identification (ELISA) of the toxin is from swabs taken from the nasal mucosa within 24 hours after inhalational exposure (36). No antibody response is induced after exposure due to the small quantity of toxin protein needed to kill. A confirmatory diagnosis comes from mouse bioassays demonstrating toxin in the blood or stool, neutralized by the appropriate antisera. There are performed by an intraperi- 
toneal application of suspicious blood, serum, gastric content on the mouse.

\section{Incidence}

In the USA, an estimated 110 cases of botulism are reported each year (35). Of these cases, approximately 25 percent are food-borne botulism, 72 percent are infant botulism and the rest are wound botulism. In 2001, 169 cases of botulism were reported. Of these, 33 were foodborne, 112 were infant botulism, and 24 were cases of wound botulism. Toxin A caused $51 \%$ of all cases, type E caused $90 \%$ of Alaska cases. A particulal food was implicated in $79 \%$ events. Most commonly home-canned vegetables (44\%). An annual incidence reach 0.1 per million (40). Georgia has the highest nationally reported rate of foodborne botulism in the world. From 1980 to 2002879 botulism cases were detected. The median annual incidence increased from 3 per million during 1980 to 1990 to 9 per million during 1991 to 2002 . In $80 \%$ of their cases were attributed to home-preserved. Fifty-eight deaths were attributed to botulism, for an average death rate of $7 \%$. The case-fatality rate ranghed from 0 to $18 \%$. The median age of patients was 34 years (range 1-90). Fifty percent were female (45). In the European Union, rates are all under 1 per million (43). Home-preserved vegetables and smoked fish are the most commonly recognized sources of botulism.

\section{Clinical Effects}

BTXs are neurotoxins that act to prevent the release of acetylcholine presynaptically and thus block neurotransmission. Illness is characterized by symmetric, descending flaccid paralysis of the motor and autonomic nerves, always beginning with the cranial nerves. Symptoms include double and blurred vision due to mydriasis, drooping eyelids, slurred speech, diplopia, ptosis and photophobia, difficulty swallowing and dry mouth. Vomiting, diarrhoea, constipation and abdominal swelling may occur. Skeletal muscle paralysis follows with a symmetrical descending and progressive weakness, which may culminate abruptly in respiratory failure. Deep tendon reflexes may be present or absent. If untreated, illness might progress to cause a descending paralysis of the respiratory muscles, arms and legs.The paralysis may make breathing difficult. There is no fever and no loss of consciousness. The symptoms can be slightly different depending on the kind of botulism (10).

The symptoms are not caused by the organism itself, but by the toxin that the bacterium releases. They usually appear within 12 to 48 hours after exposure. In case of wound botulism incubation can be longer up to 14 days. Incidence of botulism is low, but the lethality rate is high if treatment is not immediate and proper. The disease can be fatal in 5 to $10 \%$ of cases. Death can result from respiratory failure. Recovery takes months. Those who survive may have fatigue and shortness of breath for years (5).

BTX attacks the human central nervous system and blocks the release of acetylcholine, which is a neurotransmitter that acts between cells to control muscle contraction. When muscle contraction is lost, paralysis sets in, causing loss of mobility along with loss of respiratory function. Botulism patients who survive the initial onslaught oftentimes must spend weeks or months on mechanical ventilation equipment just to survive (10).

\section{Lethality}

Botulism can result in death due to respiratory failure. However, in the past 50 years the proportion of patients who die from botulism has fallen from about 50 percent to 8 percent due to advances in respiratory support available in most hospitals. All the botulinum toxins are slightly less toxic when exposure is by the pulmonary route. $\mathrm{LD}_{50}$ value for mice dosed by the intraperitoneal route for BTX type $\mathrm{A}$ is 1.0 (11) or $1.2 \mathrm{ng} / \mathrm{kg}$ (16). A recent estimate of the human $\mathrm{LD}_{50}$ of BTX-A by inhalation is $3 \mathrm{ng} / \mathrm{kg}$.

\section{Differential Diagnosis}

Single cases may be confused with various neuromuscular disorders such as atypical Guillain-Barre syndrome,

Tab. 2: Differential Diagnosis of Organophosphate Nerve Agents and Botulinum Toxin Intoxication following Inhalation Exposure.

\begin{tabular}{|l|c|c|}
\hline Toxic symptoms & Organophosphate nerve agent & Botulinum toxin \\
\hline Time & In minutes & In hours (12-48) \\
\hline Nervous & Convulsions, confusion & Progressive paralysis \\
\hline Cardiovascular & Slow heart rate & Normal rate \\
\hline Respiratory & Difficult breathing, airways constriction & Normal, then progressive paralysis \\
\hline Gastrointestinal & Increased motility, pain, diarrhea & Decreased motility, constipation \\
\hline Ocular & Miosis & Mydriasis, droopy eylids \\
\hline Salivary & Profuse, watery saliva & Normal, difficulty swallowing, dry mouth \\
\hline Lacrimal & Elevated tear release & No \\
\hline Response to atropine & Yes & $2-5$ Days \\
\hline Death & Minutes & \\
\hline
\end{tabular}


myasthenia gravis, or tick paralysis (26). Botulism could also be confused with enteroviral infections, but in these patients, fever is present, paralysis is often asymmetrical, and the CSF is abnormal. It may be necessary to distinguish nerve agent and atropine poisoning from BTX intoxication. In organophosphate nerve agent poisoning pupils are miotic and copious secretions are present. In atropine poisoning, the pupils are dilated and mucous membranes are dry, but central nervous system excitation with hallucinations and delirium is present. The differential diagnosis of organophosphate nerve agent and BTX poisoning following inhalation exposure is summarized in Table 2 (27).

\section{Decontamination}

After exposure to botulinum toxin, clothing and skin should be washed with soap and water (13). No decontamination is necessary following foodborne exposure. Following BTX aerosol exposure, skin should be rinsed with soap and water.

Equipment and contaminated objects or surfaces should be cleaned with hypochlorite solution ( 0.1 to $0.5 \%$ for 10-15 minutes) if they cannot be avoided for the hours to days required for natural degradation (38). Also soap and water should be used for clothing cleaning and for environmental decontamination.

Medical personnel caring for patients with suspected botulism should use standard precautions. Patients with suspected botulism do not need to be isolated.

\section{Prevention}

Prevention of botulism is based on good food preparation practices (particularly preservation) and hygiene. Botulism may be prevented by inactivation of the bacterial spores in heat-sterilized, canned products or by inhibiting growth in all other products. Commercial heat pasteurization (for example vacuum packed pasteurized products or hot smoked products) may not be sufficient to kill all spores and therefore safety of these products must be based on preventing growth and toxin production. Refrigeration temperatures combined with salt content and/or acidic conditions will prevent the growth or formation of toxin. If exposure to the toxin via an aerosol is suspected, in order to prevent additional exposure to the patient and health care providers, the clothing of the patient must be removed and stored in plastic bags until it can be washed with soap and water. The patient must shower thoroughly.

Food and water samples associated with suspect cases must be obtained immediately, stored in proper sealed containers, and sent to reference laboratories in order to help prevent further cases.

Botulism can be prevented by the presence of neutralizing antibody in the bloodstream. Passive immunity can be provided by equine botulinum antitoxin or by specific human hyperimmune globulin, while endogenous immunity can be induced by immunization with botulinum toxoid. Safer antitoxins and a vaccine are required to meet the threat of the use of botulinum toxin as a weapon of mass destruction (17).

\section{Prophylaxis}

Currently, there is no commercially available vaccine. A pentavalent toxoid vaccine $(\mathrm{A}, \mathrm{B}, \mathrm{C}, \mathrm{D}, \mathrm{E})$ has been developed by the US Department of Defense. This vaccine is available as an investigational new drug (contact USAMRIID, 301/619-2833). Completion of a recommended schedule $(0,2,12$ weeks) has been shown to induce protective antitoxin levels detectable at 1-year post vaccination. Routine immunization of the public, including healthcare workers, is not recommended $(4,27)$.

\section{Treatment}

Treatment is the same for inhalation (aerosolized) exposure or ingestion (foodborne). Severe botulism cases require supportive treatment, especially mechanical ventilation, which may be required for weeks or months. Antibiotics are not required (except in the case of wound botulism).

Use of antitoxin for postexposure prophylaxis is limited by its scarcity and its reactogenicity. In the United States a trivalent botulinum equine antitoxin is available and distributed for laboratory workers at high risk of exposure to BTX (38). This preparation containts 7.400 I.U. type A, 5.500 I.U. type 8 and 8.500 I.U. type $\mathrm{E}$ and is administered intravenously. This preparation has all disadvantages of an equine serum. Monoclonal antibodies should be able to remove this disadvanatages in the future $(4,27)$.

\section{Can BTX be used as a bioterrorism threat?}

Under presentment bioterrorism we usually understand the planned, unlawful use or threat of use, of biological weapons made from living organisms with the intent of causing death or disease in humans, animals, or plants. The goal of bioterrorism is usually to create fear and/or intimidate governments or societies for gaining political, religious, or ideological goals.

BTX belongs to the most dreaded potential biowarfare agents and in this case can be delivered not only as contaminated food and water but also in the form of aerosol, which produces a clinical picture very similar to food-borne intoxication, although the time to onset of the paralytic symptoms may actually be longer than for food-born cases $(27,28)$.

A team of researchers at Johns Hopkins University in Baltimore, Md., says that botulinum is a „major biological weapons threat" to the American people because it is easy to make and very deadly. Also Thomas Inglesby, M.D., a researcher with the Center for Civilian Biodefense Studies and the assistant professor of infectious diseases at Johns 
Hopkins School of Medicine said: „Botulinum toxin is a serious threat as a weapon, because it is extremely lethal and easy to produce. Only a very low quantity of toxin is needed to cause a life-threatening or fatal illness“ (9).

A biological weapon attack is difficult even to identify. The only sign may be an increase in the number of individuals infected with a certain disease. Allegations of biowarfare attack are almost always met with denials.

As for instance, causa mortis of nazi leader Reinhard Heydrich (Prague, 1942) is not completely clar*.

The Germans had BTX at their disposal, too. It can be proved by the guidelines

„Einsatzmöglichkeiten von B-Kampfmitteln zur Bekämpfung von Partisanen“ elaborated in 1943 by professor Kliewe (14). In this manual a big attention is paid to BTX.

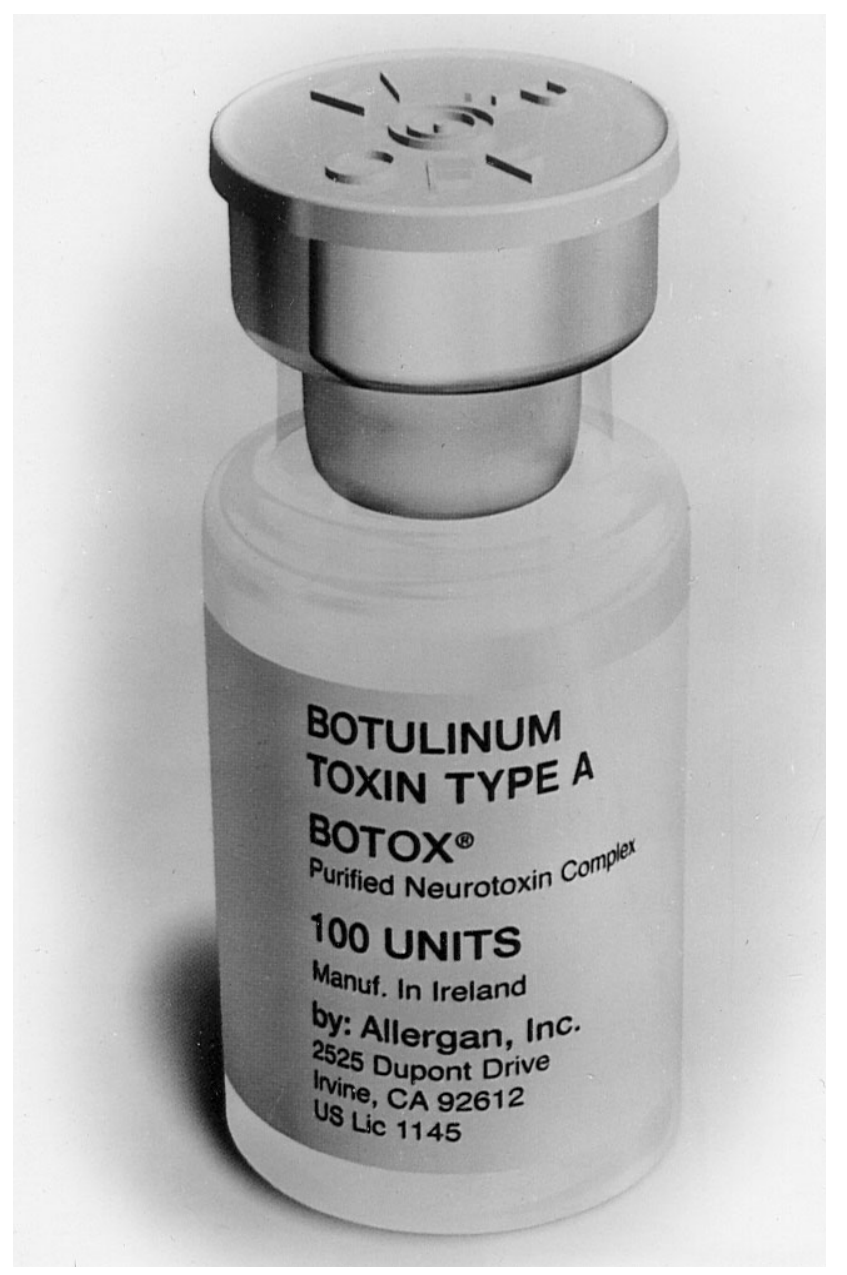

Fig. 1: One of some pharmaceutical BTX preparations.
In the 1980s in Paris a secret laboratory has been disclosed where „red army fraction“ grew Clostridium botulinum for terroristic purposes (41).

During Gulf war (1990-1991) Iraq was prepared to deploy BTX filled in bombs and missiles. Iraq's biological ofensive program has been betrayed by Karnel Hassan, Saddam Hussein's son-in-low in 1995 (23).

Religious sect Aum Shinrikjo deployed BTX aerosol, fortunately without success in Tokyo streets prior to the sarin, March, 1995 (11,41,42).

\section{BTX as medicament}

It is regrettable that botulinum toxin still needs to be considered as a bioweapon at the historic moment when it has become the first biological toxin licensed for treatment of human disease. In the United States, botulinum toxin is currently licensed for treatment of cervical torticollis, strabismus, and blepharospasm associated with dystonia (30) and in pain therapy and in particular chronic headache treatment (12).

In addition to these ophtalmologic and neurologic indications recently BTX has been applied widely also in cosmetics for wrinkle removal in the facial area. BTX reduces muscle tonus and in this way skin surface becomes smooth. For therapeutic purposes the crystalline freeze-dried BTX is produced under the trade name Botox injection or Dysport injection (Fig. 1). The application of these pharmaceutical preparations is intramuscular or hypodermic $(24,28,31,32)$.

For these reasons the simple prohibition on BTX production is not possible. Nevertheless, the threat of BTX as a biological weapon is entirely real.

\section{References}

1. Arnon SS, Schechter R, Inglesby TV, Henderson DA et al. Working Group on Civilian Biodefense. Botulinum toxin as a biological weapon: medical and public health. JAMA 2001:285:1059-70.

2. Atlas RM. Bioterriorism: from threat to reality. Annu Rev Microbiol 2002; 56:167-85

3. Broussard LA. Biological agents: weapons of warfare and bioterrorism. Mol Diagn 2001;6:323-33.

4. Byrne MP, Smith LA. Development of vaccines for prevention of botulism. Biochimie 2000;82:955-66.

5. Cherington M. Clinical spectrum of botulism. Muscle Nerve 1998;21:701-10.

6. Coleman EA, Yergler ME. Botulism. Am J Nurs 2002;102:44-7.

7. Darling RG, Catlett CL, Huebner KD, Jarrett DG. Threats in bioterrorism. I: CDC category A agents. Emerg Med Clin North Am 2002;20:273-309.

8. Dorsey EL, Beebe JM, Johns EE. Responses of air-borne Clostridium botulinum toxin to certain atmospheric stresses. Frederick, Md: US Army Biological Laboratories; October 1964. Technical Memorandum 62.

9. Dougherty J. Front Page News, Thursday, March 1, 2001. WorldNetDaily.com

10. Durand A, Serment G. Botulism toxin in practice [Article in French] Ann Readapt Med Phys 2003;46:386-8.

11. Eitzen E, Pavlin J, Cieslak T, Christopher G, Culpepper R. Medical Managemen of Biological Casualties. $3^{\text {rd }}$ Ed., Fort Detrick, Frederick USAMRIID, 1998:80 p.

\footnotetext{
* Concerning the death of nazi leader Heydrich (Prague, May 1942) there exist two explications. In October 1941, the British Secret Service requested help for operation Anthropoid, the assassination of Heydrich. Biological warfare research team at Porton Down, England, carried specially modified British No. 73 hand grenades filled with BTX. Two parachutists Josef Gabčik and Jan Kubiš members of Czechoslovak Exile Army in the UK, used these grenades on 27 May 1942. Heydrich's wounds, fragments in the chest and spleen, are ones that would not usually have been fatal at that time. However, Heydrich lapsed into coma and died. His symptomatology matches the symptoms of BTX poisoning $(22,28,29)$. Another version is as follows: Grenade fragments broke through the seat backrest where Heydrich was sitting. The seat was upholstered with horsehair which could be contaminated with Clostridium botulinum. Heydrich died of „blood poisoning“ (14).
} 
12. Evers S. Botulinum toxin and the management of chronic headaches. Curr Opin Otolaryngol Head Neck Surg 2004;12:197-203

13. Franz DR. Defense Against Toxin Weapons. Ft Detrick, Md: US Army Medica Research Institute of Infectious Diseases; 1997.

14. Geissler E. Biologische Waffen, nicht in Hitlers Arsenale. 2. Ed., Münster: LIT Verlag, 1999:905.

15. Gilbert N. Bioterrorism: better safe than sorry. Provider 2002;28:43-4

16. Gill DM. Bacterial toxins: a table of lethal amounts. Microbiol Rev 1982;46: 86-94.

17. Greenfield RA, Bronze MS. Prevention and treatment of bacterial diseases caused by bacterial bioterrorism threat agents. Drug Discov Today 2003:8:881-8.

18. Hambleton P. Botulinum toxin: structure and pharmacology. Eur Arch Otorhinolaryngol 1994;S200-2.

19. Houschild AHW: Clostridium botulinum. In: Doyle M, editor. Foodborne bacterial pathogens. New York: Marcel Dekker; 1989:112-89.

20. Huang W, Foster JA, Rogachefsky AS. Pharmacology of botulinum toxin. J Am Acad Dermatol 2000;43:249-59.

21. Josko D. Botulin toxin: a weapon in terrorism. Clin Lab Sci 2004;17:30-4.

22. Klein L, Měrka V. Biological terrorism. Rev Int Serv Santé Forces Armées 2001;74:46-8.

23. Kraatz-Wadsack G. Das Schicksal der BTW-Einrichtungen des Irak. 205-210. In: Buder E. Möglichkeiten und Grenzen der Konversion von B-WaffenEinrichtungen. 1. Ed. Münster: LIT Verlag, 2000:301.

24. Letessier S. Treatment of wrinkles with botulinum toxin. J Dermatol Treatment 1999;10:31-6.

25. Lutwick LI, Goozner B, Bourke E. Bioterrrorism: a primer for 2002. J Assoc Acad Minor Phys 2002;13:9-13.

26. Marcus N, Hourvitz A. Botulism disease [Article in Hebrew] Harefuah 2002;141:73-7, 120

27. Měrka V. Bakteriální toxiny, 147-160. In: Hrdina V et al. Př́rodní toxiny a jedy. Praha: Galén, Karolinum, 2004:302.

28. Měrka V, Fusek J. Botulinumtoxin, biologische Waffe und auch ein Arzneimittel. Schweiz. Z Militär-Katastrophen Med 2003;80:35-6.

29. Mobley JA. Biological warfare in the twentieth century, lessons from the past, challenges for the future. Mil Med 1995;160:547-53

30. O'Day J.Use of botulinum toxin in neuro-ophthalmology. Curr Opin Ophthalmol 2001;12:419-22.

31. Patočka J. Botulotoxin - užitečný jed. Kontakt 2002;4:23-9.

32. Patočka J, Špliňo M. Botulinum toxin: From poison to medicinal agent. ASA Newsletter 2002;8:14-9

33. Robinson RF, Nahata MC. Management of botulism. Ann Pharmacother 2003 ;37:127-31.

34. Rossetto O, Deloye F, Poulain B, Pellizzari R, Schiavo G, Montecucco C. The metallo-proteinase activity of tetanus and botulism neurotoxins. J Physiol Paris 1995;89:43-50.
35. Shapiro RL, Hatheway C, Swerdlow DL. Botulism in the United States: a clinical and epidemiologic review. Ann Intern Med 1998;129:221-8.

36. Sesardic D, Jones RG, Leung T, Alsop T, Tierney R. Detection of antibodies against botulinum toxins. Mov Disord 2004;19(Suppl.8):S85-91.

37. Siegel LS. Destruction of botulinum toxin in food and water. In: Hauschild AH, Dodds KL, eds. Clostridium botulinum: Ecology and Control in Foods. New York, NY: Marcel Dekker Inc, 1993:323-41.

38. Siegel LS. Human immune response to botulinum pentavalent (ABCDE) toxoid determined by a neutralization test and by an enzyme-linked immunosorbent assay. J Clin Microbiol 1988;26:2351-6.

39. Simpson LL. Kinetic studies on the interaction between botulinum toxin type $A$ and the cholinergic neuromuscular junction. J Pharmacol Exp Ther 1980;212:16-21.

40. Sobel J, Tucker N, Sulka A, McLaughlin J, Maslanka D. Foodborne botulism in the United States, 1990-2000. Emerg Infect Dis 2004;10:1606-11. (http:// www.cdc.gov/ncidod/EID/vol10no9/pdfs/03-0745.pdf)

41. Sohns T. Die Proliferation von Massenvernichtungswaffen. Notfallvorsorge 2000 2:1-15

42. Sugishima M. Aum Shinrikyo and the Japanese law on bioterrorism. Prehospital Disaster Med 2003;18:179-83.

43. Therre H. Botulism in the European Union. Euro Surveill 1999;4:2-7.

44. Varkey P, Poland GA, Cockerill FR $3^{\text {rd }}$, Smith TF, Hagen PT. Confronting bioterrorism: physicians on the front line. Mayo Clin Proc 2002;77:661-72.

45. Varma JK, Katsitadze G, Moiscrafishvili M et al. Signs and symptoms predictive of death in patients with foodborne botulism - Republic of Georgia, 1980-2002. Clin Infect Dis 2004;39:357-62.

46. Wiener SL. Strategies for the prevention of a successful biological warfare aerosol attack. Mil Med 1996;161:251-6.

Submitted October 2004.

Accepted December 2004.

Prof. RNDr. Jiř́i Patočka, DrSc., University of Defence, Faculty of Military Health Sciences, Department of Toxicology, 50001 Hradec Králové, Czech Republic. e-mail: patocka@pmfhk.cz 